JOURNAL OF INSTITUTE OF ECONOMIC DEVELOPMENT AND SOCIAL RESEARCHES

ISSN: 2630-6166

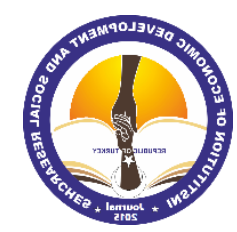
International Refereed \& Indexed
2017
Open Access Refereed E-Journal
Vol:3 / Issue:6
iksadjournal.com / iksadjournal@gmail.com
p.48-52

Article Arrival Date 28/07/2017

\title{
DETERMINATION OF COMPONENT COMPOSITION OF CHICORIUM PLANT
} CHICORIUM ӨCIMAIГIHIH КОМПОНЕНTTI ҚҰРАМЫН АНЫҚТАУ

\author{
G.E. AZIMBAEVA
}

Ph Doctorate student M.B.Akhtayeva, Kazakh State Women's Teacher Training University, azimbaeva_g@mail.ru, Almaty/Kazakhistan

\begin{abstract}
This article describes the composition of the Cichorium plant (flower, leaf, leaf). The $\mathrm{pH}$ value of Cichorium plant (flower, leaf, leaf) was determined at $\mathrm{pH}$ value of the mark «I-160 MI». Extracted water was $80 \%$ ethyl alcohol and 2 hours in water. The moisture content of the Cichorium plant by gravimetric method, acidity, ascorbic acid, pectinic substances by tectimetric method, the size of macro-micro elements in the AAnalyst 400 by atomic-emission semiconductor spectral analysis and spectrophotometer at atomic absorbing method Shimadzu on the «AA 7000», Cichorium plant The photocalorimetry method was determined by photocalorimeter KFK-2 and KFK-3, protein Kvelald, by the method of photocororimetry, anthocyanes, flavonoids, polyphenols, carotene and sugar. Kleachatka AE By Ermakov's modification, using weight method, the crude fat content was determined by the Weight Method by Soxle Apparatus.

The elemental size of the Cichorium plant (flower, stalk, leaf) was determined. As a result, it has been shown that copper, zinc, manganese, iron, cobalt, cadmium, calcium, magnesium, potassium, sodium are present. Also, according to the study, Cichorium plant contains flavonoids, proteins, pectinic substances, antibodies, anthocyanins, phenolic acids, carotene, polyphenols, and gumers.
\end{abstract}

Keywords: Cichorium, polyphenol, extraction, anthocyanin, coumarin, carotene.

\section{ТУЙІНДЕМЕ}

Бұл мақалада Cichorium өсімдігінің (гүлі, сабағы, жапырағы) компонентті құрамы анықталған. Cichorium өсімдігі (гүлі, жапырағы, сабағы) рН мәні «И-160 МИ» маркалы рН метрінде анықталды. Экстрактивтілігі суда және 80\% этил спиртінде 2 сағат уақытта жүргізілді. Cichorium өсімдігінің ылғалдылығы мен күлділігі гравиметриялық әдіспен, қышқылдылығы, аскарбин қышқылы, пектинді заттары титриметриялық әдіспен, макро-микро элементтердің мөлшері атом-эмиссионды жартылай сандық спектрлік анализ әдісімен AAnalyst 400 приборында және атомды-абсорбциялық әдіспен спектрофотометр «АA 7000» Shimadzu приборында, Cichorium өсімдігінің құрамындағы антоциандар, флаваноидтар, полифенолдар, каротин және қант мөлшері фотокалориметрлік әдіспен КФК-2 және КФК-3 маркалы фотокалориметрінде, белок Къельдаль әдісімен анықталды. Клечатка А.Е. Ермаковтың модификациясы бойынша салмақтық әдіспен, шикі май мөлшері Сокслет аппаратының көмегімен салмақтық әдісімен анықталды.

Cichorium өсімдігінің (гүлі, сабағы, жапырағы) элементтік мөлшері анықталды. Нәтижесінде құрамында мыс, мырыш, марганец, темір, кобальт, кадмий, кальций, магний, калий, натрий кездесетіндігі көрсетілді. Сондай-ақ, зерттеу нәтижесі бойынша Cichorium өсімдігінің құрамында флавоноидтар, белок, пектинді заттар, илегіш заттар, антоциандар, фенол қышқылдары, каротиндер, полифенолдар, кумариндер кездеседі.

Кілт сөздер: Cichorium, полифенол, экстракция, антоциан, кумарин, каротин.

Табиғат алуан түрлі өсімдікке бай, хош иісі адамды сергітіп, бойға жаңа күш-қуат береді. Улы деген өсімдіктің өзі пайдалы, одан жанға шипа дәрі- дәрмек жасалады.

Дәрілік өсімдіктер, шипалы өсімдіктер - медицинада және мал дәрігерлігінде емдеу және аурудың алдын алу мақсатында қолданылатын өсімдіктер. Қазақстанда өсетін алты мыңнан астам өсімдік түрінің бес жүздей түрі дәрілік өсімдіктерге жатады.

Адамзат баласына белгілі, бірақ қасиеттері мен құндылығы толық зерттелмеген тұқымдастың бірі - күрделігүлділер тұқымдасы. Бұл топ өкілдерінің басым бөлігі мәдени өсімдіктер ретінде, әрі жабайы түрде өсетін түрлері аз зерттелгендіктен, XXI ғасырда дүниежүзі ғалымдарының 
қызығушылығын тудырып отырған тұқымдастың бірі. Қазақстанда кездесетін бұл тұқымдастың бір өкілі - Chichorium өсімдігі[1]. Аталған тұқымдастың өкілі негізінен жергілікті флорада жер талғамай, кез - келген жерлерде өсе беретін арамшөп ретінде кеңінен таралған.

Cichorium (Шашыратқы) - көп жылдық шөптесін өсімдіктер тегі. Дүние жүзінде қоңыржай және субтропиктік аймақтарда өсетін 8 - 10 түрі белгілі. Cichorium тамыры терең ұзындығы 30 см, бұтақты, етті шырынға өте бай. Таралуы: жабайы шашыратқы құрғақ, күнді жерде өседі. Шөл далада, жол бойларында және далалы жерлерде, көбіне Ресей, Батыс Сібір, Кавказда таралған. Көптеген халықаралық емдеу тәсілдерінде шашыратқы қолданылады. Ол бүйрек, бауыр ауруларында, көкбауырды емдейді [1,3].

Химиялық құрамы толық зерттелмеген өсімдіктердің қасиеттерін зерттеу, биологиялық және физиологиялық активті заттарды бөлу биоорганикалық химия саласындағы өзекті мәселелердің бірі [5]. .

Отандық бірегей фитопрепараттарды кешенді түрде биологиялық белсенді заттардан іздестіруден бастап, дәрілік шикізатты өсіру, оларды өңдеп, жаңа фитопрепараттардың дайын дәрілік түрлерінің тәжірибелік-өнеркәсіптік мөлшерін шығаруға дейін жеткізу жұмыстарының бастамасы ретінде осы ғылыми жобаны жолға қоюдамыз. Аталған бағыттағы іргелі зерттеулерді іске асыру барысында Қазақстан өсімдіктерінің бірнеше түрлері Университет қабырғасында зерттелуде. Бұлардан мыңнан астам табиғи қосылыстар бөлініп, теңдестіріліп, мыңға жуық жаңа туындылар синтезделеді деп күтілуде [1,3].

Зерттеудің мақсаты: Cichorium өсімдігінің (гүлі, жапырағы, сабағы) компонентті құрамын анықтау.

Зерттеудің нысаны ретінде ОҚО, Мақтаарал ауданының 2017-2018жж Cichorium өсімдігі (гүлі, сабағы, жапырағы) алынды.

\section{Тәжірибелік бөлім:}

Cichorium өсімдігі (гүлі, жапырағы, сабағы) рН мәні «И-160 МИ» маркалы рН метрінде анықталды.

Cichorium өсімдігінің ылғалдылығы мен күлділігі гравиметриялық әдіспен, қышқылдылығы, аскарбин қышқылы, пектинді заттары титриметриялық әдіспен анықталды. Экстрактивтілігі суда және 80\% этил спиртінде 2 сағат уақытта жүргізілді [4]. Зерттеу нәтижелері 1-кестеде көрсетілген.

Кесте - 1. Cichorium өсімдігінің (гүлі, сабағы, жапырағы) химиялық құрамы

\begin{tabular}{|c|c|c|c|c|c|c|c|c|c|c|}
\hline \multirow[t]{2}{*}{ № } & \multirow[b]{2}{*}{ Шикізат атауы } & \multirow[b]{2}{*}{ 壳 } & \multirow{2}{*}{ 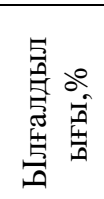 } & \multirow{2}{*}{ 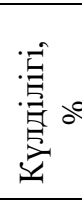 } & \multicolumn{2}{|c|}{ Экстрактивтілігі, \% } & \multirow{2}{*}{$\begin{array}{c}\dot{5} \\
\text { 普。 } \\
\text { 是 } \\
\end{array}$} & \multirow{2}{*}{ 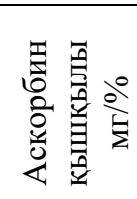 } & \multicolumn{2}{|c|}{ Пектинді заттар, \% } \\
\hline & & & & & Суда & Спиртте & & & $\begin{array}{c}\text { Суда } \\
\text { еритін }\end{array}$ & $\begin{array}{c}\text { Суда } \\
\text { ерімейтін }\end{array}$ \\
\hline 1 & $\begin{array}{l}\text { Cichorium гүлі } \\
\text { (Мақтаарал ауд.) }\end{array}$ & $\begin{array}{l}\text { in } \\
\text { in }\end{array}$ & 15,8 & 2,90 & 35,06 & 23,84 & 0,30 & 4,60 & - & - \\
\hline 2 & $\begin{array}{l}\text { Cichorium сабағы } \\
\text { (Мақтаарал ауд.) }\end{array}$ & $\underset{\infty}{\infty}$ & 17,9 & 3,40 & 36,42 & 26,94 & 0,10 & 6,50 & 0,04 & 0,09 \\
\hline 3 & $\begin{array}{l}\text { Cichorium жапьрағы } \\
\text { (Мақтаарал ауд.) }\end{array}$ & 8 & 16,7 & 2,50 & 38,56 & 25,53 & 0,25 & 5,40 & 0,03 & 0,04 \\
\hline
\end{tabular}


1-кестеде көрсетілген мәліметтеріне сүйенсек, Cichorium сулы ерітіндісінің рН мәндері әлсіз қышқылдық ортаны көрсетеді. Сондай-ақ, экстрактивтілігі суда спиртпен салыстырғанда 1,31,5 аралығнда жоғары. Cichorium өсімдігі аскорбин қышқылына бай екенін көруімізге болады. Аскорбин қышқылының мөлшері Cichorium өсімдігінің гүлімен салыстырғанда жапырағында 1,4 есе, сабағында 1,17 есе көп. Пектинді заттарының мөлшері сабағы мен жапырағында аз мөлшерде кездеседі.

Cichorium өсімдігінің құрамындағы антоциандар, флаваноидтар, полифенолдар, каротин және қант мөлшері фотокалориметрлік әдіспен КФК-2 және КФК-3 маркалы фотокалориметрінде, белок Къельдаль әдісімен анықталды. Клечатка А.Е. Ермаковтың модификациясы бойынша салмақтық әдіспен, шикі май мөлшері Сокслет аппаратының көмегімен салмақтық әдісімен анықталды. Зерттеу нәтижелері 2-кестеде көрсетілген.

Кесте - 2. Cichorium өсімдігінің (гүлі, сабағы, жапырағы) компонентті құрамы

\begin{tabular}{|c|c|c|c|c|c|c|c|c|c|c|c|}
\hline \multirow[t]{2}{*}{ № } & \multirow{2}{*}{ 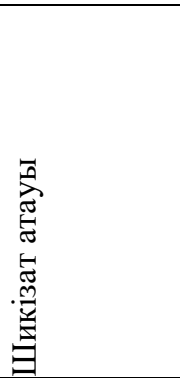 } & \multirow{2}{*}{ 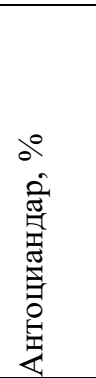 } & \multirow{2}{*}{ 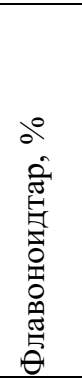 } & \multirow{2}{*}{ 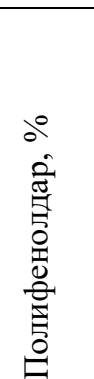 } & \multicolumn{2}{|c|}{ 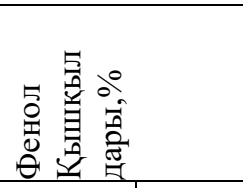 } & \multirow{2}{*}{ 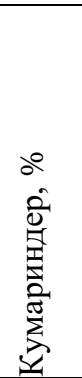 } & \multirow[b]{2}{*}{ 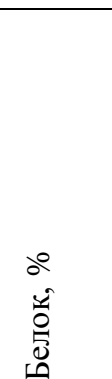 } & \multirow[b]{2}{*}{ 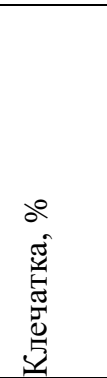 } & \multirow[b]{2}{*}{ 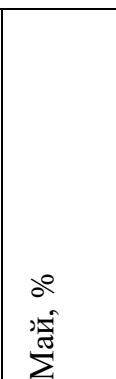 } & \multirow{2}{*}{ 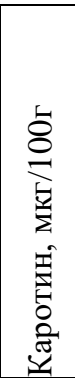 } \\
\hline & & & & & 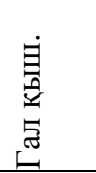 & 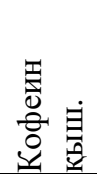 & & & & & \\
\hline 1 & 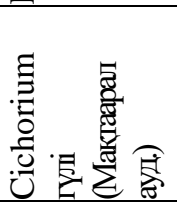 & 0,350 & 2,33 & 0,06 & - & - & - & 16,75 & 31,70 & 12,45 & 283 \\
\hline 2 & 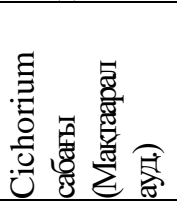 & 0,035 & 1,06 & 0,06 & 3,06 & 3,37 & 0,38 & 6,50 & 61,30 & 1,06 & 106 \\
\hline 3 & 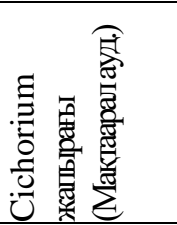 & 0,080 & 0,58 & 0,07 & 11,03 & 12,13 & 3,72 & 16,19 & 31,40 & 1,95 & 345 \\
\hline
\end{tabular}

2-кесте мәліметтері бойынша Cichorium өсімдігінің антоцианның мөлшері гүлінде сабағымен салыстырғанда 10 есе, жапырағымен салыстырғанда 4,3 есе көп. Флаваноид мөлшері гүлінде жапырағымен салыстырғанда 3 есе көп, Полифенол мөлшері 0,06-0,07 аралығында өзгереді. Фенол қышқылдарының ішіндегі галл қышқылы мен кофеин қышқылы гүлінде кездеспейді, алайда, галл қышқылының мөлшері сабағына қарағанда жапырағында 3,6 есе, ал кофеин қышқылы 3,5 есе жоғары. Кумариннің мөлшері гүлінде кездеспегенімен сабағымен салыстырғанда жапырағында 9 есе көп. Май ең көп мөлшерде гүлінде көп кездесіп, 12,45 \% құрады.

Cichorium өсімдігінің жер үстіңгі бөлігінің (гүлі, жапырағы, сабағы) құрамындағы макромикро элементтердің мөлшері атом-эмиссионды жартылай сандық спектрлік анализ әдісімен AAnalyst 400 приборында және атомды-абсорбциялық әдіспен спектрофотометр «АА 7000» Shimadzu приборында анықталды. Зерттеу нәтижесінде алынған мәліметтер 3-кестеде көрсетілген. 
Кесте - 3. Cichorium өсімдігінің (гүлі, сабағы, жапырағы) элементтік мөлшері

\begin{tabular}{|c|c|c|c|c|c|c|c|c|c|c|}
\hline Шикізат & $\begin{array}{l}\mathrm{Cu} \\
\mathbf{M \Gamma / \kappa \Gamma}\end{array}$ & $\begin{array}{l}\text { Zn } \\
\text { МГ/кГ }\end{array}$ & $\begin{array}{l}\text { Mn } \\
\text { Мг/кГ }\end{array}$ & $\begin{array}{l}\mathbf{F e} \\
\text { мГ/кГ }\end{array}$ & $\begin{array}{l}\text { Сo } \\
\text { МГ/кГ }\end{array}$ & $\begin{array}{l}\text { Cd } \\
\text { MГ/KГ }\end{array}$ & $\begin{array}{l}\text { Ca } \\
\%\end{array}$ & $\begin{array}{l}\text { Mg } \\
\%\end{array}$ & $\begin{array}{l}\mathbf{K} \\
\%\end{array}$ & $\begin{array}{l}\mathrm{Na} \\
\%\end{array}$ \\
\hline 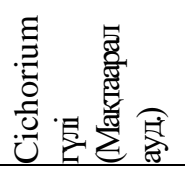 & $\begin{array}{l}0 \\
0 \\
0 \\
0\end{array}$ & $\begin{array}{l}\bar{n} \\
\hat{0} \\
0\end{array}$ & $\frac{ \pm}{0}$ & $\begin{array}{l}\infty \\
\infty \\
\text { n. }\end{array}$ & $\ddot{0}$ & $\begin{array}{l}\tilde{\delta} \\
8 \\
\dot{0}\end{array}$ & $\stackrel{\cong}{\cong}$ & है & n & $\begin{array}{l}\tilde{y} \\
\tilde{\delta}\end{array}$ \\
\hline 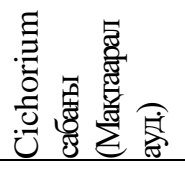 & 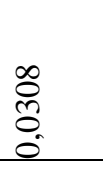 & $\begin{array}{l}\stackrel{+}{N} \\
\text { Oे } \\
0\end{array}$ & $\vec{\infty}$ & $\begin{array}{l}\text { fo } \\
i \\
\text { in }\end{array}$ & $\stackrel{m}{8}$ & $\begin{array}{l}\text { ô. } \\
\text { o. }\end{array}$ & $\stackrel{\infty}{\stackrel{\infty}{=}}$ & $\begin{array}{l}\infty \\
\infty \\
0\end{array}$ & $\begin{array}{l}\nexists \\
i\end{array}$ & $\begin{array}{l}n \\
\tilde{0} \\
0\end{array}$ \\
\hline 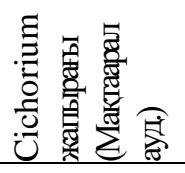 & 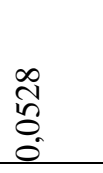 & $\begin{array}{l}\frac{1}{5} \\
0 \\
0\end{array}$ & $\begin{array}{l}\frac{n}{1} \\
\tilde{0} \\
0\end{array}$ & $\begin{array}{l}\bar{\sigma} \\
\dot{\gamma}\end{array}$ & $\begin{array}{l}n \\
\delta \\
0\end{array}$ & $\tilde{\delta}_{0}$ & $\stackrel{\infty}{\stackrel{2}{=}}$ & $\cong$ & $\stackrel{2}{2}$ & $\frac{2}{0}$ \\
\hline
\end{tabular}

3-кестеде көрсетілгендей, cichorium өсімдігінің макро-микроэлементтер мөлшері ШРК аспайды.

Қорытындылай келе Cichorium өсімдігінің химиялық құрамында кездесетін қосылыстар медицинада түрлі ауруларды емдеуде, отандық дәрі-дәрмек жасауда, фармацевтиканың дамуына өз үлесін қосады. Айталық, полифенолдардың қатерлі ісік және жүрек ауруларына қарсы әсері жақсы. Ағзаның А дәруменіне мұқтаждығы табиғи каротиндердің есебінен айтарлықтай дәрежеде қамтамасыз етіледі. Каротиндерді тағамдарды және мал азықтарын дәрумендеу кезінде терінің зақымдануын емдеуде және тағамның бояғыш заты ретінде пайдаланады.

\section{Қорытынды:}

1. Қазақстанда өсетін Cichorium өсімдігінің (гүлі, сабағы, жапырағы) компонентті құрамы анықталды.

2. Cichorium өсімдігінің (гүлі, сабағы, жапырағы) элементтік мөлшері анықталды. Нәтижесінде құрамында мыс, мырыш, марганец, темір, кобальт, кадмий, кальций, магний, калий, натрий кездесетіндігі көрсетілді.

3. Cichorium өсімдігінің химиялық құрамы анықталып, құрамында ең көп мөлшерде кездесетін биологиялық белсенді заттары көрсетілді. Олар - флавоноидтар, белок, пектинді заттар, илегіш заттар, антоциандар, фенол қышқылдары, каротиндер, полифенолдар және кумариндер.

\section{Пайдаланылған әдебиеттер тізімі:}

1. Г.Ш.Бурашева, Б.Қ.Есқалиева, А.К.Умбетова «Табиғи қосылыстар химиясының негіздері», Алматы, 2013ж.

2. Растения полная энциклопедия., Москва: «Эксмо» 2005г. с.211.

3. Химия и применение природных и синтетических биологических активных соединений. Изд: «Комплекс». Алматы, 2004г.

4. Б.К.Ескалиева, «Фитохимический анализ лекарственного растительного сырья», $2012 \Gamma$.

5. Введение фитохимические исследования и выявление биологической активности веществ растений. Алматы, 2008ж.

6. Музычкина Р.А., Корулькин Д.Ю., Абилов Ж.А. «Основы химии природных соединений», Алматы, Қазақ университеті, 2010г. 
7. М.Б.Ахтаева, Г.Е.Азимбаева., «Шашыратқы гүлінен эфир майын бөлу және құрамын идентификациялау», «Жаратылыстану пәндері саласындағы ғылым мен білімнің даму тенденциясы» атты халықаралық ғылыми-практикалық материалдары, Алматы, 7-8 қазан, 2016ж. 